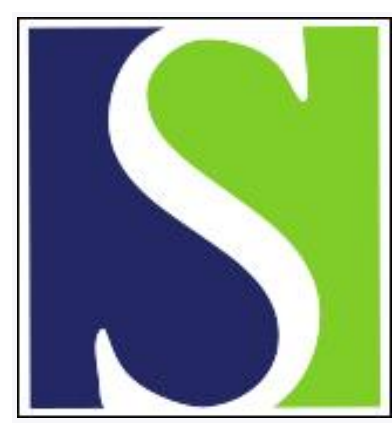

Scand J Work Environ Health 1988;14(4):231-238

https://doi.org/10.5271/sjweh.1927

Issue date: Aug 1988

Impact of work-related and psychosocial factors on the development of ischemic heart disease among urban bus drivers in Denmark.

by Netterstrom B, Juel K

Affiliation: Danish Institute for Clinical Epidemiology, Copenhagen.

This article in PubMed: www.ncbi.nlm.nih.gov/pubmed/3175555

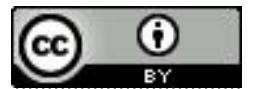




\title{
Impact of work-related and psychosocial factors on the development of ischemic heart disease among urban bus drivers in Denmark
}

\author{
by Bo Netterstrøm, MD, Knud Juel ${ }^{1}$
}

\begin{abstract}
NETTERSTRØM B, JUEL K. Impact of work-related and psychosocial factors on the development of ischemic heart disease among urban bus drivers in Denmark. Scand J Work Environ Health 14 (1988) 231-238. From 1978 to 1985,2465 male bus drivers in the three major cities in Denmark were followed with regard to hospital admission due to myocardial infarction (MI) and death due to ischemic heart disease (IHD). In all $2045(83 \%)$ of these men responded in 1978 to a questionnaire on psychosocial well-being and work conditions. The respondents did not differ from the nonrespondents regarding hospital admissions and death in the follow-up period (1978-1984). Sixty-two cases of MI were registered among the 2045 bus drivers in 1978-1984. On this basis relative risk for MI was calculated with a multiple regression model for independent variables regarding psychosocial well-being and work conditions. High work load (driving in heavy traffic) was significantly associated with the occurrence of MI. Of the psychosocial factors "no social contact with colleagues" and "increased work pace" were also significantly associated with the occurrence of MI. Smoking habits tended to be associated with the occurrence of MI, while stress symptoms and job dissatisfaction did not. The mental burden on bus drivers working in heavy traffic seems a possible explanation for the findings.
\end{abstract}

Key terms: follow-up study, myocardial infarction, social contact, smoking, work load, work pace.

In 1978 studies of the health and well-being of bus drivers in Denmark were conducted. A historic-prospective cohort study of all bus drivers employed by the traffic companies in Odense, Aarhus, and Copenhagen - the three major cities in Denmark in 1977 was carried out, as was a cross-sectional study based on questionnaires sent to all employed bus drivers in the three cities. These studies were followed by a clinical investigation of a representative random sample of the earlier subjects.

The cohort study established a higher incidence of ischemic heart disease among bus drivers than among men actively employed in Denmark (31). The crosssectional study demonstrated a higher prevalence of questionnaire-positive angina pectoris among bus drivers than among locomotive engineers (27). Studies from London and Norway have reported similar results $(16,26)$. The bus drivers in the Danish studies demonstrated a marked maladaptation to work, experienced poor work environment, and evinced pronounced mental symptoms. Since poor occupational well-being has been found to be related to the incidence of ischemic heart disease in other investigations $(9,17$, $22,30,40$ ), the psychosocial work environment and conditions of strain under which bus drivers work could be essential factors in the development of

\footnotetext{
1 The Danish Institute for Clinical Epidemiology, Copenhagen, Denmark.
}

Reprint requests to: Dr B Netterstrøm, The Danish Institute for Clinical Epidemiology, 25, Svanemøllevej, Copenhagen $\varnothing$, Denmark. ischemic heart disease. We have therefore tried to elucidate these possible connections in a prospective cohort study.

\section{Subjects and methods}

The study population included all male bus drivers who were employed full-time by the traffic companies in Copenhagen, Aarhus, and Odense on 1 April 1978. Questionnaires were sent to all of the 2693 bus drivers on 1 April 1978. Seventy-two of the drivers did not have driving duty at that time, and 156 of the drivers were women. These two groups were excluded from the study. A total of 2045 of the 2465 men included $(83 \%)$ answered and returned the questionnaire.

The 2465 bus drivers were followed from 1 April 1978 to 31 December 1985 with regard to ischemic heart disease. Deaths from this disease [International Classification of Diseases (ICD) 410-414] and firsttime hospital admissions due to acute myocardial infarction (ICD 410) were used as measures for the occurrence of ischemic heart disease. First-time admissions due to acute myocardial infarction were selected since acute myocardial infarction normally results in exclusion from work and early retirement, and exposure to the work of driving ceases. None of the bus drivers had previously suffered from episodes of acute myocardial infarction at the start of the follow-up period.

In 1986 all 2465 bus drivers were traced in the Register of Causes of Death and the Danish National 
Patient Register according to their national personal identification numbers. These registers record all deaths based on death certificates and hospital admissions based on reports furnished by the hospitals, respectively. Information as to cause and date of death was obtained from the Register of Causes of Death up to and including 31 December 1985, and data on the admission diagnoses from the National Patient Register up to and including 31 December 1984.

The classification of the causes of death was conducted by the National Board of Health, and the classification of the admission diagnoses was conducted by the physicians at the individual hospitals. In both processes the eighth revision of the ICD classification of the World Health Organization was used. Records on all cases of myocardial infarction were collected from the hospitals. In all cases the diagnosis was based on enzyme elevation or electrocardiographic changes.

The independent variables used in this investigation were taken from the 1978 questionnaire study (27), in which the information on psychosocial and work conditions was collected. (See the appendix.)

The objective work load was estimated from the traffic intensity to which the bus drivers were exposed in 1978. As regards the Copenhagen bus drivers, a driver who was not acquainted with the study classified the Copenhagen routes into two groups, one with routes going through heavily trafficked streets and the other going through less trafficked streets. One group of drivers could not be classified as they had duty on

Table 1. Age distribution of respondents and nonrespondents in 1978.

\begin{tabular}{lccccc}
\hline \multirow{2}{*}{$\begin{array}{l}\text { Age } \\
\text { years) }\end{array}$} & \multicolumn{2}{c}{ Respondents $^{\mathbf{a}}$} & & \multicolumn{2}{c}{ Nonrespondents } \\
\cline { 2 - 3 } \cline { 5 - 6 } & $\mathrm{N}$ & $\%$ & & $\mathrm{~N}$ & $\%$ \\
\hline $20-29$ & 355 & 17 & & 112 & 27 \\
$30-39$ & 448 & 22 & & 94 & 22 \\
$40-49$ & 420 & 21 & & 73 & 17 \\
$50-59$ & 621 & 30 & & 104 & 25 \\
$60-64$ & 201 & 10 & & 37 & 9 \\
\hline Total & 2045 & 100 & & 420 & 100 \\
\hline
\end{tabular}

a Mean age 43.7 (SD 12.3) years.

b Mean age 41.2 (SD 13.1) years.

Table 2. Age-standardized morbidity ratio (SMR) of first time hospital discharges among the nonrespondents, respondents used as reference. (O=observed number of cases, $\mathrm{E}=$ expected number of cases, $95 \% \mathrm{Cl}=95 \%$ confidence interval)

\begin{tabular}{lrrrr}
\hline Diagnoses $^{\mathrm{a}}$ & $\mathrm{O}$ & $\mathrm{E}$ & SMR & $95 \% \mathrm{Cl}$ \\
\hline $\begin{array}{l}\text { Myocardial infarction } \\
\text { (ICD 410) }\end{array}$ & 10 & 10.9 & 92 & $44-169$ \\
$\begin{array}{l}\text { Cardiovascular disease, others } \\
\text { (ICD 390-458 excluding 410) }\end{array}$ & 40 & 32.9 & 122 & $87-166$ \\
Others & 121 & 111.2 & 109 & $90-130$ \\
All causes & 171 & 155 & 110 & $94-116$ \\
\hline
\end{tabular}

a Code of the International Classification of Diseases (ICD), eighth revision, in parentheses. various routes. In Aarhus and Odense the classification was performed according to the drivers' statements as to whether they worked on routes in the center of the city or mainly in the suburbs in 1978.

The remaining variables were constructed on the basis of replies to the questionnaire regarding work and private life conditions, often with a number of reply options. These variables were generally dichotomized into a positive or negative reply in the data analysis.

The independent variables with a statistically significant association with ischemic heart disease were chosen on the basis of the chi-square test in two-way contingency tables. A Cox regression model was set up to analyze the simultaneous contribution of these variables.

By backward elimination the variables with no significant association to ischemic disease were removed. The resulting model was then supplemented by all the other variables individually to determine whether some of them contributed significantly. Firstorder interactions were tested in the final model. The proportionality assumption was examined graphically.

The relative risks for all the independent variables, significant as well as nonsignificant, are given in the results section. The final model supplied the relative risks for the significant variables; for the nonsignificant variables the relative risks were determined by supplementing the final model with the variable.

\section{Results}

The age distribution of the respondents and nonrespondents is given in table 1 . There were relatively more nonrespondents in the younger age group. Information provided by the bus drivers' union indicated that some of the younger drivers were newly employed and thus they may not have been motivated to participate in the study.

Table 2 shows the age standardized morbidity ratio for the nonrespondents with the respondents as the reference. It is noteworthy that the incidence of admission to the hospital due to acute myocardial infarction was not higher among the nonrespondents.

During the period 1978-1985, 130 deaths occurred among the 2465 bus drivers. Forty-one were due to ischemic heart disease, 47 due to cancer, and 11 were suicides. None of the causes of death differed significantly in frequency from the mortality among Danish men in 1981, as the expected values after indirect age standardization was 44,48 and 8 , respectively.

The number of first-time hospital admissions within each group of diagnoses during the almost seven-year follow-up period is shown in table 3. Cardiovascular disease was the most frequent cause of admission and myocardial infarction the most frequent individual diagnosis ( 72 cases in all). Sixty-two of the men with myocardial infarction had answered the questionnaire 
in 1978. According to the questionnaire fifty of them had had no symptoms of angina pectoris in 1978 (36). Twenty-one of the 62 respondents who developed acute myocardial infarction during the follow-up period died of acute myocardial infarction.

By the Cox regression model, the relative risk for hospital admission due to acute myocardial infarction in the whole follow-up period was calculated for each of the independent variables. (See table 4.) Moreover, the relative risk was calculated only for the period in which each person had worked as a bus driver. Work load $(\mathrm{P}=0.0009)$ and age $(\mathrm{P}<0.0001)$ contributed significantly to the regression model when the complete follow-up period was considered. Social contact with colleagues in spare time $(\mathrm{P}=0.04)$ and work pace higher than five years earlier $(P=0.02)$ contributed to the model as well when only the period while the person was a bus driver was included in the calculation. In the latter analysis the P-value for work load was 0.0002 , and that for age 0.0001 .

From table 4 it can be seen that smoking was not significantly associated with acute myocardial infarction $(\mathrm{P}=0.06)$ when the complete follow-up period was considered. Nor could significant differences be found when the smokers were divided into the two groups of heavy smokers and smokers of less than 20 cigarettes or $20 \mathrm{~g}$ of tobacco daily. However, it must be emphasized that, of the 62 respondents who developed acute myocardial infarction, only one was a nonsmoker. (See table 5.) Thus the calculation of the relative risk was uncertain. The remaining indicators of subjective work load, job satisfaction, stress, and so-

Table 3. Distribution of the diagnoses of the bus drivers discharged from the hospital in 1978-1984. Only the first discharge in each group of diagnoses is included.

\begin{tabular}{lr}
\hline Diagnosis $^{3}$ & Number \\
\hline Cardiovascular disease (ICD 390-458) & 244 \\
Hypertension (ICD 400-404) & 25 \\
Myocardial infarction (ICD 410) & 72 \\
lschemic heart disease, others & 45 \\
(ICD 411-414) & 25 \\
Cerebrovascular disease (ICD 430-438) & 24 \\
Varices (ICD 454) & 24 \\
Hemorrhoidal tumor (ICD 455) & 29 \\
Others & 107 \\
Respiratory disease (ICD 460-519) & 40 \\
Gastroduodenal ulcer (ICD 531-534) & 52 \\
Back disease (ICD 353.99, 713.11-713.14, & 82 \\
$717.09,725-728.79)$ & 156 \\
Cancer (ICD 140-209) & 268 \\
Accidents (ICD 800-999) & 949 \\
Others & \multicolumn{2}{c}{9} \\
\hline Total & \\
\hline Code of the International Classification of Diseases (ICD), \\
eighth revision, in parentheses.
\end{tabular}

Table 4. Relative risk for first admission due to acute myocardial infarction (MI) among 2045 male urban bus drivers in $1978-1984$. (95\% $\mathrm{Cl}=95 \%$ confidence interval)

\begin{tabular}{|c|c|c|c|c|}
\hline & & 984 & Bus & time \\
\hline & $\begin{array}{l}\text { Relative } \\
\text { risk }\end{array}$ & $95 \% \mathrm{Cl}$ & $\begin{array}{l}\text { Relative } \\
\text { risk }\end{array}$ & $95 \% \mathrm{Cl}$ \\
\hline$<7$ years in school $/>8$ years & 1.1 & $0.6-1.9$ & 1.2 & $0.6-2.6$ \\
\hline Smoker/nonsmoker & 5.0 & $0.7-36.0$ & 3.0 & $0.4-22.1$ \\
\hline Ex-smoker/nonsmoker & 3.2 & $0.4-25.6$ & 1.6 & $0.1-12.8$ \\
\hline Work load (objective) & & & & \\
\hline $\begin{array}{l}\text { Copenhagen high/low } \\
\text { Province high/low }\end{array}$ & $\begin{array}{l}2.7 \\
3.4\end{array}$ & $\begin{array}{l}0.9-7.6 \\
1.2-9.5\end{array}$ & $\begin{array}{l}6.2 \\
4.4\end{array}$ & $\begin{array}{l}0.8-46.9 \\
1.2-16.4\end{array}$ \\
\hline Work load (subjective) & & & & \\
\hline $\begin{array}{l}\text { Family problems due to shift work, yes/no } \\
\text { Feeling of monotony, yes/no } \\
\text { Work pace too high, yes/no } \\
\text { Work pace higher than } 5 \text { years ago, yesino }\end{array}$ & $\begin{array}{l}1.0 \\
1.0 \\
0.8 \\
1.4\end{array}$ & $\begin{array}{l}0.6-1.7 \\
0.6-1.6 \\
0.4-1.7 \\
0.8-2.6\end{array}$ & $\begin{array}{l}1.0 \\
0.9 \\
1.0 \\
2.7\end{array}$ & $\begin{array}{l}0.5-1.9 \\
0.5-1.8 \\
0.3-3.0 \\
1.1-7.1\end{array}$ \\
\hline Social network indicators & & & & \\
\hline $\begin{array}{l}\text { Married/unmarried } \\
\text { Social contact with colleagues in spare time, } \\
\text { nolyes }\end{array}$ & 1.4 & $0.2-10.5$ & 2.0 & $1.0-3.8$ \\
\hline Job satisfaction indicators & & & & \\
\hline $\begin{array}{l}\text { Looking for other work, yes/no } \\
\text { Feeling of influence on work, yes/no } \\
\text { Dissatisfaction with wages, yes/no } \\
\text { Dissatisfaction with the administration, yes/no }\end{array}$ & $\begin{array}{l}1.1 \\
1.4 \\
1.3 \\
1.2\end{array}$ & $\begin{array}{l}0.6-2.1 \\
0.7-3.0 \\
0.7-2.1 \\
0.7-2.1\end{array}$ & $\begin{array}{l}1.3 \\
1.5 \\
1.1 \\
1.5\end{array}$ & $\begin{array}{l}0.6-2.8 \\
0.6-4.0 \\
0.5-2.0 \\
0.8-3.0\end{array}$ \\
\hline Stress indicators & & & & \\
\hline $\begin{array}{l}\text { Unbalanced several times a month, yes/no } \\
\text { Mentally exhausted several times a month. }\end{array}$ & 1.0 & $0.6-1.7$ & 0.8 & $0.4-1.7$ \\
\hline $\begin{array}{l}\text { yes/no } \\
\text { Physically exhausted several times a month, }\end{array}$ & 1.1 & $0.7-2.0$ & 1.5 & $0.9-3.2$ \\
\hline $\begin{array}{l}\text { yes/no } \\
\text { Insomnia several times a month, yes/no }\end{array}$ & $\begin{array}{l}0.7 \\
0.8\end{array}$ & $\begin{array}{l}0.3-1.3 \\
0.5-1.3\end{array}$ & $\begin{array}{l}0.8 \\
0.9\end{array}$ & $\begin{array}{l}0.3-1.7 \\
0.5-1.6\end{array}$ \\
\hline yes/no & 1.1 & $0.7-1.8$ & 1.4 & $0.7-2.6$ \\
\hline
\end{tabular}

a See the text. 
Table 5. Number of cases of hospital admission due to acute myocardial infarction and the one-year incidence per 1000 persons for 2045 male urban bus drivers in Denmark in 1978-1984, distributed according to the significant factors and smoking.

\begin{tabular}{|c|c|c|c|c|}
\hline & \multicolumn{2}{|c|}{$\begin{array}{c}1978-1984 \\
(N=62)\end{array}$} & \multicolumn{2}{|c|}{$\begin{array}{l}\text { Time as bus driver } \\
(N=40)\end{array}$} \\
\hline & Cases & Incidence & Cases & Incidence \\
\hline $\begin{array}{l}\text { Work load in Copenhagen high } \\
\text { Work load in Copenhagen low } \\
\text { Work load in Copenhagen mixed } \\
\text { Work load in province high } \\
\text { Work load in province low }\end{array}$ & $\begin{array}{r}27 \\
4 \\
12 \\
14 \\
5\end{array}$ & $\begin{array}{l}7.1 \\
3.1 \\
2.6 \\
9.7 \\
2.5\end{array}$ & $\begin{array}{r}16 \\
1 \\
10 \\
10 \\
3\end{array}$ & $\begin{array}{l}7.8 \\
1.3 \\
2.9 \\
8.3 \\
2.0\end{array}$ \\
\hline $\begin{array}{l}\text { Pace higher than } 5 \text { years ago } \\
\text { Pace not higher than } 5 \text { years ago }\end{array}$ & $\begin{array}{l}49 \\
13\end{array}$ & $\begin{array}{l}5.9 \\
2.5\end{array}$ & $\begin{array}{r}35 \\
5\end{array}$ & $\begin{array}{l}5.8 \\
1.4\end{array}$ \\
\hline $\begin{array}{l}\text { Social contact with colleagues in } \\
\text { spare time } \\
\text { No social contact with colleagues } \\
\text { in spare time }\end{array}$ & $\begin{array}{l}28 \\
34\end{array}$ & 2.2 & 15 & $\begin{array}{l}2.9 \\
5.8\end{array}$ \\
\hline $\begin{array}{l}\text { Smoker (>20 cigarettes/daily) } \\
\text { Smoker }(<20 \text { cigarettes/daily) } \\
\text { Ex-smoker } \\
\text { Never smoker }\end{array}$ & $\begin{array}{r}14 \\
32 \\
9 \\
1\end{array}$ & $\begin{array}{l}4.3 \\
5.2 \\
3.5 \\
0.7\end{array}$ & $\begin{array}{r}10 \\
20 \\
5 \\
1\end{array}$ & $\begin{array}{l}4.6 \\
6.4 \\
3.1 \\
0.9\end{array}$ \\
\hline
\end{tabular}

cial network were not associated with acute myocardial infarction. It must be pointed out, however, that only 256 of the bus drivers were unmarried or divorced. All the bus drivers who developed myocardial infarction were married. Therefore, no estimation of relative risk was made.

The relative risk of hospital admission due to acute myocardial infarction in relation to the independent variables was calculated both with and without control for age. The result was in agreement with those of the multiple regression analysis.

The distribution of acute myocardial infarction cases according to the variables with significant association to myocardial infarction and smoking category is shown in table 5. Sixty-two cases were included in the analysis for the whole observation period, while 40 drivers were admitted to the hospital with acute myocardial infarction while employed as bus drivers.

The incidence of acute myocardial infarction in the high workload groups was more than twice that of the other groups of bus drivers. The incidences in the high workload groups was approximately the same for bus drivers in Copenhagen and the two smaller cities. The other independent variables showed the same degree of statistical association to subsequent myocardial infarction as was determined in the multiple regression analysis.

The association between the independent variables and death due to ischemic heart disease was analyzed with the use of the 32 cases who had died due to ischemic heart disease. In the period 1978-1984, 21 of these had been hospitalized with acute myocardial infarction.

Because of the large person-coincidence between ischemic heart disease deaths and hospital admittances due to acute myocardial infarction, the same association pattern between the ischemic heart disease deaths and the independent variables was seen. (See table 4.)

\section{Discussion}

The results of this study demonstrate that Danish urban bus drivers with routes in the center of town have a higher risk of developing ischemic heart disease than their colleagues who have routes in the suburbs.

The feeling of increasing work pace was associated with a subsequent development of acute myocardial infarction as well. The drivers who had no social contact with colleagues in spare time showed a higher risk of developing acute myocardial infarction than those who had such contact. No connection could be found between myocardial infarction and subjective stress symptoms and job dissatisfaction. The risk of the never smokers was nonsignificantly lower than that of the smokers.

Selection mechanisms could not directly explain these findings. The bus drivers studied were employed as civil servants on the same terms. The terms normally exclude employment as a bus driver in cases of excessive overweight, previous episodes of acute myocardial infarction, severe hypertension, and age above $\mathbf{4 0}$ years. Previous investigations (21) have found that almost all bus drivers over 40 years of age in the three cities in question had been employed by the transit company for most of their active worklife. The bus drivers are employed as civil servants and as such must have a medical examination every fifth year in order to have their driver's licenses renewed. This process results in considerable selection among especially highrisk bus drivers. However, the process is the same for both the suburban drivers and the urban drivers. In comparisons with other Danish men this selection would be important.

Exclusion from work could, nevertheless, have significance with respect to the results of our study. However, we have taken into consideration the secondary selection in the analysis of acute cases of 
myocardial infarction that developed during employment as a bus driver. Moreover, in the cross-sectional study in 1978 only 12 out of 62 who later developed acute myocardial infarction had symptoms of chest pain that could indicate angina pectoris.

On the other hand, there could be some question about validity with regard to misclassification of exposure. The variable "objective work load" was determined according to the route of each driver in 1978. It is possible that some drivers switched routes after that rate. Such an event has not been registered in the study. Therefore the work load could have been smaller for a driver who had switched to a less busy route. The opposite could have been the case for a driver who had switched to a busier route, but who, in this study, was classified as having a nonstraining route. Both an increase and a decrease in work load during the observation period would contribute to an underestimate of the extent of exposure. Empirically, the majority of the bus drivers are on the same routes for many years, especially if they have routes in the suburbs. If route switches are made, it normally results in work on the same type of route (city/suburb).

Similarly, the drivers' psychosocial circumstances may have changed during the follow-up period, a fact that may lead to bias and, as a result, conceal a connection between acute myocardial infarction and such factors.

As confounders, only age and smoking were controlled for in the study. However, smoking habits did not influence the results essentially. It has been shown that the Copenhagen bus drivers had both a higher systolic and diastolic blood pressure than other unskilled workers in Copenhagen (28). Serum cholesterol was found to be higher in bus drivers than in other men, and it normalized after retirement from work (28). Similar results were found in England and Norway $(13,26)$. As some of the mechanisms leading to the elevated relative risk among urban bus drivers could have been affected by serum cholesterol and blood pressure due to stress $(8,11)$, a confounder control with regard to these risk factors would lead to overmatching and reduce the ef fect of the objective work load (38).

The results of our study agree with those of previous investigations with regard to external validity. In other studies such a pronounced association between objective work load and ischemic heart disease has not been found, however. Rosenmann \& Friedman (37) reanalyzed the data of Morris et al from the 1950s (25) and found that the bus drivers in central London had a relative risk of ischemic heart disease just below 2 in comparison to that of the tram drivers in the suburbs of London. Ahlbom \& Theorell (2) obtained a similar result in Stockholm in the 1970s. The two different methods used to evaluate the work load in Copenhagen and in the province support the validity of our results.

The fact that city bus drivers constitute an especially high-risk group regarding ischemic heart disease can hardly be attributed to other factors than the ones related to work conditions. An air pollution factor could be taken into consideration, but measurements of carbon monoxide and hydrocarbons performed on Copenhagen bus routes in 1979 did not indicate such a connection. In ordinary passenger transport, the carbon monoxide concentrations in the buses did not normally exceed $10 \mathrm{ppm}$ (3). Nor was lung cancer found to be more frequent among the bus drivers in the city (29).

It seems more likely that the traffic load and many contacts with passengers are the factors that separate the two types of routes. It is evident that, at least in Copenhagen, the routes contributing two or more cases of acute myocardial infarction almost all pass through relatively narrow streets in the center of the city, while the majority of the routes that did not contribute any cases of acute myocardial infarction pass through less busy streets. (See figure 1.)

Karasek's job-strain model has demonstrated that the combination of increased work pace and lack of influence on job situation contributes to an excessive risk of ischemic heart disease $(19,20)$. We have estimated that the influence on job situation is almost similar for both suburban and city bus drivers, whereas the work load is assessed to be highest among the city bus drivers, due to traffic problems particularly.

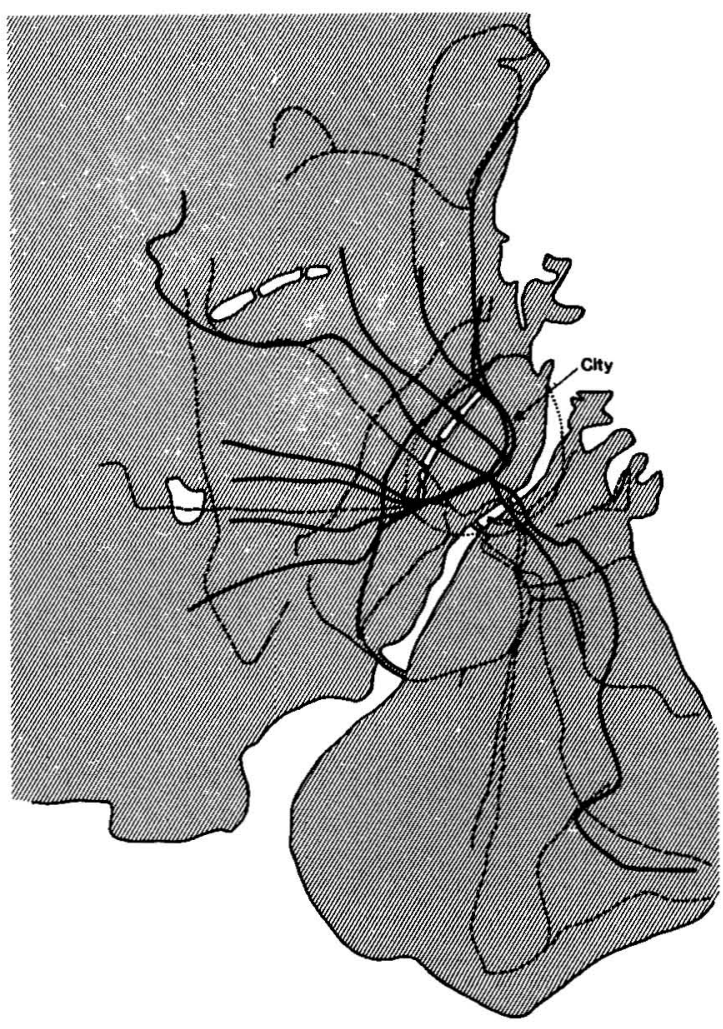

Figure 1. Routes contributing two or more cases of myocardial infarction (MI) (-) and routes without any MI (-.-) in Copenhagen in 1978-1984. 
A number of indicators, such as social network, symptoms of stress, and job satisfaction, were found in a number of other studies to be associated with ischemic heart disease $(5-7,10,14,24,33,34$, 40-42). However, generally, several population groups from various social statuses and occupations have been included in these studies, and it is possible that the mentioned factors are, to a certain degree, indicators of more profound, underlying factors, such as conditions of life.

In one of the few prospective investigations in which the association between ischemic heart disease and stress and work load in a group of people with identical life conditions was studied, no association was found (4). Only angina pectoris and chronic disease in general were found to be associated with stress and experienced work load.

We found no connection between years of schooling and subsequent myocardial infarction. Other inrestigations in which association between ischemic heart disease and education was studied and found have focused to a higher degree on education after termination of school $(12,15,16)$.

Recently, shift work has been found to be associated with ischemic heart disease (1). However, in our study familial problems due to shift work did not seem to influence the occurrence of ischemic heart disease.

None of the stress indicators nor the variables dealing with job satisfaction had any significant association with ischemic heart disease. This result is worth noting, as a number of studies have demonstrated an association between satisfaction, nervous symptoms, and ischemic heart disease $(10,14,15,24)$. This fact could indicate that the independent variables used in our study could not characterize the situation of the individual bus driver to a sufficient degree.

A study among policemen in Finland (32) indicated that more extensive evaluations are necessary to give a psychological characteristic of groups at high risk of ischemic heart disease. Furthermore, research on type A behavior suggests that a connection between acute myocardial infarction and type of personality is more complex than the methods used in our study can reveal $(18,23)$. Suppressed aggression seems to be an essential factor in "the coronary prone behavior" (23), and therefore the independent variables employed in our study with regard to satisfaction and nervousness were probably unsuitable to reveal a connection between acute myocardial infarction and experienced conditions of life.

It is perhaps the physiological stress that is of significance in this context rather than the driver's expression of his feelings about the work situation. Some studies have found physiological changes which could indicate an elevated risk of ischemic heart disease while driving a bus. Electrocardiographic changes during straining automobile driving (39) and an elevated secretion of catecholamines and cortisol in the urine of drivers in heavy traffic (35) suggest a neurogenic and hormonal strain on the heart under such conditions.

In summary our study showed that objective work load, as measured by traffic intensity, was the factor with the strongest association to subsequent hospital admission due to myocardial infarction. Lack of social contact with colleagues in spare time and the feeling of increased work pace were associated with myocardial infarction as well, while other work-related and psychosocial factors had no connection with myocardial infarction in this prospective study.

\section{Acknowledgments}

The study was supported by Sygekassernes Helsefond, grant no $\mathrm{H} 11 / 47-84$.

We thank Ms LS Eriksen for her help with the register linkage and data processing, Ms S Brenaa for typing the manuscript, and Ms $\mathrm{H}$ Faergeman for translating the text.

\section{References}

1. Åkerstedt T, Knutsson A, Alfredsson L, Theorell T. Shift work and cardiovascular disease. Scand J Work Environ Health 10 (1984) 409-414.

2. Ahlbom A, Theorell T. Hjärtinfarkt hos trafikpersonal vid Stock holms lokal trafik AB [Myocardial infarction in personnel employed by the Stockholm Traffic Company]. The National Institute for Psychosocial Factors and Health, Stockholm 1981.

3. Andreasen H. Buschaufførers arbejdsmiljø: Tekniske målinger [The working environment of bus drivers: Technical measurements]. Arbejdsmiljøfondet, Copenhagen 1981.

4. Aro S. Stress morbidity and health related behaviour. Scand J Soc Med 25 (1981) 1-130.

5. Berkman L. Social network analysis and coronary heart disease. Adv Cardiol 29 (1982) 37-49.

6. Berkman L, Syme L. Social network, host resistance and mortality: A nine year follow-up study of Alameda county residents. Am J Epidemiol 109 (1979) 186-204.

7. Bruhn JG, Chandler BA, Lynn TN, Wolf S. Social characteristics of patients with coronary heart disease. Am J Med Sci 251 (1966) 629-637.

8. Cobb S, Rose RM. Hypertension, peptic ulcer and diabetes in air traffic controllers. J Am Med Assoc 224 (1973) 489-492.

9. Dorian B, Taylor CB. Stress factors in the development of coronary artery disease. J Occup Med 26 (1984) $747-756$.

10. Floderus B. Psycho-social factors in relation to coronary heart disease and associated risk factors. Nord Hyg Tidskr 6 (1974) $1-55$.

11. Friedmann $\mathbf{M}$, Rosenman $\mathrm{RH}$, Carol V. Changes in serum cholesterol and blood clotting time in men subjective to cyclic variation of occupational stress. Circulation 17 (1958) 852-861.

12. Gillum RF, Paffenbarger RS. Chronic disease in former college students. Am J Epidemiol 108 (1978) 289-298.

13. Hartvig $\mathbf{P}$, Midttun D. Coronary heart disease risk factors in bus and truck drivers. Int Arch Occup Environ Health 52 (1983) 353-360.

14. Haynes SG, Fenleib M, Levine S, Scotch N, Kannel W. The relationship of psychosocial factors to coronary heart disease in the Framingham study. Am J Epidemiol 107 (1978) 384-399. 
15. Hinkle $\mathbf{L}$, Shekelle R. Educational status and risk of coronary heart disease. Science 163 (1969) 98.

16. Holme I, Hegeland A, Hjermann I, Leren P, Lund Larsen PG. Koronare risikofaktorer og socioøkonomisk status [Coronary risk factors and socioeconomic status]. Tidsskr Nor Lægeforen 27 (1977) 1380-1382.

17. House JS. Occupational stress and coronary heart disease. J Health Soc Behav 15 (1974) 12-27.

18. Jenkins $C D$. Recent evidence supporting psychologic and social risk factors for coronary heart disease. N Engl J Med 294 (1976) 1033-1038.

19. Karasek R, Baker D, Marxer F, Ahlbom A, Theorell T. Job decision latitude, job demands and cardiovascular disease: A prospective study of Swedish men. Am J Publ Health 71 (1981) 1-30.

20. Karasek KA, Theorell T, Schwartz J, Pieper C, Alfredsson L. Job, psycho-social factors and coronary heart disease. Adv Cardiol 29 (1982) 62-67.

21. Laursen P, Netterstrøm B, Bedersen TK, WhittaJørgensen A. Buschaufførers arbejdsmiljø [The working environment of bus drivers]. Institute of Social Medicine, University of Copenhagen, Copenhagen, 1980. (Publication 11).

22. Lind $\mathbf{E}$, Theorell $T$. Sociological characteristics and myocardial infarctions. J Psychosom Res 17 (1973) $59-73$.

23. Matthews K, Glass D, Rosenman R, Bortner R. Competitive pattern and coronary heart disease. J Chronic Dis 30 (1977) 489-498.

24. Medalie JH, Goldbourt U. Angina pectoris among 10.000 men: Psychosocial and other risk factors as evidenced by a multivariate analysis of a five year incidence study. Ann J Med 60 (1976) 910-921.

25. Morris JN, Heady JA, Raffle PAB, Robers CG, Parks JW. Coronary heart disease and physical activity of work. Lancet 2 (1953) 1053-1057.

26. Morris JN, Kagan A, Pattison DC, Gardner MJ, Raffle $P A B$. Incidence and prediction of ischaemic heart disease in London busmen. Lancet 2 (1966) 553-559.

27. Netterstrøm B. Helbredsforhold blandt buschauffører [A cross-sectional investigation of the health of bus drivers]. Ugeskr Læger 144 (1982) 1795-1801.

28. Netterstrøm B, Danborg L, Kirchhoff M. Traditionelle coronare risikofaktorer hos bybuschauffører [Traditional coronary risk factors in urban bus drivers]. Ugeskr Læger (in press).
29. Netterstrøm B, Juel K. Cancer among urban bus drivers. Int Arch Occup Environ Health (in press).

30. Netterstrøm B, Kristensen TS. Psykiske belastninger, stress og iskæmisk hjertesygdom [Psychosocial strain, stress and ischæmic heart disease]. Ugeskr Læger 148 (1986) $271-275$.

31. Netterstrøm B, Laursen P. Incidence and prevalence of ischaemic heart disease among urban bus drivers in Copenhagen. Scand J Soc Med 9 (1981) 75-79.

32. Nirrko O, Lauroma M, Siltanen $P$, Tuominen $H$, Vanhala K. Psychological risk factors related to coronary heart disease: Prospective studies among policemen in Helsinki. Acta Med Scand 212 (1982): suppl 660, $137-146$.

33. Orth-Gomer K. Studies on ischaemic heart disease. University of Stockholm, Stockholm 1979. (Doctoral dissertation)

34. Orth-Gomer K, Perski A, Theorell T. Psychosocial factors and cardiovascular disease. The National Institute for Psychosocial Factors and Health, Stockholm 1983.

35. Rissler A, Aronsson G. Stress reactions among busdrivers in the traffic of Stockholm. Department of Psychology, University of Stockholm, Stockholm 1982.

36. Rose $G$, Blackburn. Cardiovascular survey methods. World Health Organization, Geneva 1968.

37. Rosenmann RH, Freidman M. The possible relationship of occupational stress to clinical coronary heart disease. Calif Med 89 (1958) 169-174.

38. Rothman KJ. Modern epidemiology. Little, Brown and Company, Boston, MA 1986.

39. Simonsen E, Baker C, Burns N. Cardiovascular stress produced by driving an automobile. Am Heart J 75 (1968) 125-135.

40. Theorell T, Floderus-Myrhed B. Work load and risk of myocardial infarction: A prospective psychosocial analysis. Int J Epidemiol 6 (1977) 17-21.

41. Valkonen T. Psychosocial stress and sociodemographic differentials in mortality from ischaemic heart disease in Finland. Acta Med Scand 212 (1982): suppl 660, 152-164.

42. Van Dykhuizen N, Reiche H. Psychosocial stress in industry: A heartache for middle management. Psychother Psychosom 34 (1980) 124-134.

Received for publication: 29 September 1987

\section{Appendix}

\section{Independent variables obtained by a questionnaire in 1978}

Variable

Town of work

Age

Years in school

Smoking habits

Work load

Family problems due to shiftwork

Feeling of monotony

Work pace

\section{Question}

Case number

What is your age?

How many years have you gone to school?

Do you smoke?

Have you been a smoker?

How much do you smoke every day?

What route number do you work on?

Do you mostly work in the city

or in the suburb?

Do the shiftwork hours cause

problems in the family?

Is your work varied or is it monotonous?

Is the work pace too high?
Answer

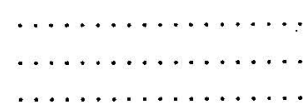

Yes/no

Yes/no

Yes/no

Yes/no 
Work pace higher than

5 years ago

Married/unmarried

Social contact with

colleagues in spare time

Looking for other

work

Feeling of influence on work

Dissatisfaction with wages

Dissatisfaction with

the administration

Unbalanced

Mentally exhausted

Physically exhausted

Insomnia

Stress
Is the work pace higher, lower or the same as 5 years ago?

What is your marital status?

Do you often visit some of your colleagues in your spare time?

Are you thinking of trying to get another job?

Do you have any influence on the organization of your work?

How satisfied are you with the wages you get for your work?

How satisfied are you with the administration of the company?

Are you often nervous or unbalanced? (often $=$ more than once a month)

Do you often feel mentally exhausted after work? (often $=$ more than once a month)

Do you often feel physically exhausted at work? (often $=$ more than once a month)

Is it often difficult for you to fall asleep? (often $=$ more than once a month)

Have you several times a month felt so stressed that you wanted to desert the bus while on route?
Higher/lower/the same

Yes/no

Yes/no

Yes/no

Satisfied/

dissatisfied

Satisfied/

dissatisfied

Yes/no

Yes/no

Yes/no

Yes/no

Yes/no 